Europe's Journal of Psychology, 6(3), pp. 94-121

www.ejop.org

\title{
Bad Humor, Bad Marriage: Humor Styles in Div orced and Married Couples
}

\author{
Vassilis Saroglou \\ Department of Psychology, Université catholique de Louv ain
}

Christelle Lacour

Department of Psychology, Université catholique de Louvain

\section{Marie-Eve Demeure}

Department of Psychology, Université catholique de Louvain

\begin{abstract}
Humor has been found to play a key role in close relationships, including marriage. The objective of the present work was to investigate the role of specific humor styles, i.e. affiliative, self-enhancing, aggressive, earthy, and self-defeating, with regard to (a) relationship quality among married and divorced people and (b) divorced versus married status. We compared men and women from 98 married and 48 divorced couples (total $N=292$ ) who evaluated their humor styles, anxiety and avoidance in attachment, marital satisfaction, and (ex-)spouse's humor styles. Constructive humor (self-enhancing and/or affiliative), especially among men, was related to increased relationship satisfaction and to non-divorced status. Self-defeating humor, especially among women, predicted marital satisfaction but also divorce. Use of antisocial humor (aggressive and earthy), especially by men, predicted divorce and was related to low (retrospective) relationship quality among divorced couples. Humor styles were unique predictors of divorce beyond the impact of insecure attachment. Finally, partner similarity in the high or low use of self-defeating humor and the (transgressing social norms) earthy humor was observed in both the married and divorced, but the latter were dissimilar in the high or low use of humor styles implying positive or negative quality in interpersonal relations. Partners' humor styles provide unique and gender-specific information to our understanding of factors influencing marital stability and dissolution.
\end{abstract}


Is humor, as often believed, an important ingredient for quality in romantic relationships, especially among married couples? Previous research has investigated this question but often done so treating humor as a global trait without distinguishing between different humor styles. More intriguing: do specific humor styles contribute to marital stability and, consequently - by their absence or because of their quality to relationship dissolution and divorce? As far as we know, there is no empirical research on this issue. Finally, the quality of humor styles and, subsequently, their positive versus negative role in a couple's relationship, may just be an artifact of general positivity or negativity in the way partners see themselves or the other in the relationship, i.e. anxiety or avoidance in attachment. Do humor styles play an additive, unique role in predicting marriage stability or dissolution?

The objective of the present study was to investigate whether specific humor styles may play a role in marital (in)satisfaction and marital (in)stability, as well as whether the role of humor styles in predicting divorce is unique, i.e. exists beyond the possible influence of the quality of adult attachment. Two kinds of samples were included, i.e. divorced and married couples; and both husbands and wives (or ex-spouses) provided an evaluation of their humor styles as well of the humor styles of their partner. Below, we will review the relevant literature and develop specific hypotheses.

\section{Humor Styles in Romantic Relationships and Marriage}

Humor is an important ingredient in a partner's attractiveness and its presence increases desirability for a romantic relationship (Bressler \& Balshine, 2006; Lippa, 2007). Note however that these effects are more present in women's perception of men's attractiveness; and they are accompanied by the idea that humorous individuals, although more socially adapted, may be less intelligent and trustworthy than their non-humorous counterparts. Sharing humorous experiences during a first encounter between strangers leads to greater feelings of closeness (Fraley \& Aron, 2004), and young dating couples' similarity in humor appreciation of the same material was found to be related to their predisposition to marry the partner (Murstein \& Brust, 1985).

Many people will take the step to become involved in a relationship with, or even to marry, such a desirable partner. Does humor contribute to, or at least reflect, relationship satisfaction? The existing evidence is somewhat in fav or of this idea but this evidence is sometimes inconsistent, indirect, or more complex. Use of humor by newly married wives (but not husbands) in problem-solving in a laboratory study, was 
correlated positively with the wives' marital satisfaction; there was also a high correspondence between spouses on use of humor (Cohan \& Bradbury, 1997). However, in that study, husbands' humor seemed to contribute to marital instability when spouses reported more major life events (possibly, this humor was used as an avoiding coping mechanism). In a similar study, humor was related to observed affection between spouses (Johnson, 2002). Interestingly, positive perception of the spouse's humor was also found to relate positively to one's own marital satisfaction (Ziv \& Gadish, 1989) and negatively to marital discord (Rust \& Goldstein, 1989). Married people seem to attribute the success of their marriage, among other things, to the humor and laughter they share (Laver, Laver, \& Kerr, 1990; Ziv, 1988), but spouse similarity in humor appreciation of the same material was found to be unrelated to marital affection (Priest \& Thein, 2003).

In these studies, humor was measured as a unidimensional construct. However, recent conceptualization and research using the Humor Styles Questionnaire(HSQ; Martin, Puhlik-Doris, Larsen, Gray, \& Weir, 2003; see also Martin, 2007) has established the existence, distinctiveness, and divergent external outcomes of at least four humor styles: (a) affiliative (or social), (b) self-enhancing (or use of humor as positive coping), (c) aggressive, and (d) self-defeating. These humor styles differ in the way one includes or disparages others in humor (respectively, a and c), and the way one strengthens or diminishes the self (respectively, b and d). As summarized recently (Veselka, Schermer, Martin, \& Vernon, 2010, p. 772): "Affiliative humor involves the use of joking and friendly humorous banter to facilitate interpersonal bonds. Selfenhancing humor is characterized by the ability to find amusement in life's stresses. Aggressive humor entails the use of sarcasm and put-downs to hurt or manipulate others. And self-defeating humor represents individuals' attempts to amuse others by making excessively disparaging humorous remarks about themselves". These four styles have theoretical and content proximity with most of the six bipolar humor types measured by the Humorous Behavior Q-Sort Deck (HBQD; Craik, Lampert, \& Nelson, 1996). The latter offers an additional humor style, called "earthy vs. repressed", that is defined as delight and non inhibition in joking about taboo topics: macabre, sexual, scatologic al, vulgar.

We hypothesized that, overall, the two positive humor styles, i.e. affiliative and selfenhancing will relate positively to relationship quality, because they express either a solid self that overcomes life's adversities (self-enhancing) or concern for interpersonal bonds through humor (affiliative). The opposite would be the case for the two negative humor styles, because, through humor, they diminish others (aggressive) or the self (self-defeating). Since a marital relationship involves (at least) 
two, both other-directed and self-directed humor styles should play a role. No specific hypotheses were made with regard to the earthy humor style.

Personality and mental health-related correlates of the four humor styles are in fav or of these hypotheses. The two positive humor styles reflect high self-esteem, emotional intelligence, positive emotions, optimism, and intimacy. The other two dimensions are associated with hostility, neuroticism, and psychological distress; and self-defeating humor in particular is associated with sociotropy (dependence and excessive need to please others), loneliness, and burnout (Martin, 2007, for review; see in addition, Fitts, Sebby, \& Zlokovich, 2009; Frewen, Brinker, Martin, \& Dozois, 2008; Kuiper \& McHale, 2009; Tümkaya, 2007; Vernon et al., 2009). Each of these psychological dimensions are important for intrapsychic and interpersonal functioning, particularly within close relationships. Finally, no clear predictions could be made on the association between marital satisfaction and earthy humor. On one hand, this humor style reflects openness to experience and flexibility (Craik et al., 1996; Craik \& Ware, 1998), although it is unclear whether this means something more (e.g., creativity) than simply low conservatism. On the other hand, appreciation of sick humor seems to be characteristic of people with low emotional responsiveness (Herzog \& Anderson, 2000; Herzog \& Karafa, 1998), but also of people who, in their coping, are characterized by social expression of emotions (Saroglou \& Anciaux, 2004).

In fav or of our expectations, there is some initial and indirect evidence from research that distinguishes between humor styles diverging in quality. Self-reported use of positive and negative humor when interacting with the partner was, respectively, positively and negatively associated with relationship satisfaction among students (Butzer \& Kuiper, 2008; the effect was stronger in a conflict scenario) and married couples (De Koning \& Weiss, 2002; both spouses' humor was related to each partner's satisfaction). In a direct observation setting where dating student couples were involved to a conflict discussion task, individuals whose partners used more affiliative and less aggressive humor during the discussion were more satisfied with their relationship and reported an increase in perceived closeness and better resolution following the discussion (Campbell, Martin, \& Ward, 2008). The role of selfenhancing and self-defeating humor was not investigated in that study. In sum, no study, to our knowledge, has investigated how several distinct humor styles, as stable personality characteristics of one and/or the other partner, are related to the quality of relationship among married couples. 


\section{Humor Styles, Relationship Dissolution, and Divorce}

Do humor styles play a role in predicting div orce of married couples? For the same reasons applied above to married couples, we hypothesized that affiliative and selfenhancing humor may contribute to "prevent" divorce, and should thus be more present among married than divorced couples. Similarly, self-defeating and aggressive humor may "facilitate" divorce and should therefore be more present among divorced compared to married couples. No prediction was made regarding the role of earthy humor. The same hypotheses were made regarding the relation between humor styles and the relationship quality of divorced participants during their marriage.

Divorce, and relationship dissolution more generally, is a result of an accumulation of, and interactions between, a series of factors relative to each partner's and the couple's enduring vulnerabilities, stressful events, and adaptive processes. Low use of self-enhancing humor is a good candidate to explain marital instability since this humor style serves by definition as a coping mechanism against life's adversities. The lack of successful emotional regulation in marital interaction is found to predict divorce (Rodrigues, Hall, \& Fincham, 2006). Low use of affiliative humor and high use of aggressive humor may also predict insatisfaction and relationship dissolution, since behaviors denoting hostility (e.g., reject) and lack of warmth (e.g. no cooperation, no enjoyment) in marital interaction, were found to predict divorce in wellestablished marriages (e.g., Matthews, Wickrama, \& Conger, 1996). High use of earthy humor could predict divorce, since, by its socially transgressive character, this humor style may reflect personality tendencies (e.g., negative individualism: Kirsh \& Kuiper, 2003) that can reasonably be conceived as predicting divorce. On the other hand, its strong personality correlate, Openness to Experience (Craik \& Aron, 1998), is known to be a positive ingredient in marriage (McCrae \& Sutin, 2009). Finally, high use of self-defeating humor should be a predictor of marital dissolution since this humor style reflects neuroticism, negative emotionality, and excessive dependence, all of which are typically predict div orce (Rodriguez et al., 2006, for review).

There is some suggestive, intriguing, yet inconsistent evidence on the role of humor in general (but not on specific humor styles) on relationship dissolution and divorce. Longitudinal research, where specific characteristics observed in spouse interaction at one point in time were examined as predictors of marital stability or dissolution many years later, did not provide consistent evidence in fav or of humor. Humor has no effect; or has a positive effect for marital stability; or has a negative effect if it is husbands' humor that could be seen as a tool used to avoid facing problems 
(Cohan \& Bradbury, 1997; Gottman, 1994; Gottman \& Levenson, 1999; Gottman, Coan, Carrere, \& Swanson, 1998). Dating couples of university students who engaged in affiliative humor (Doris, 2004, as cited in Martin, 2007) or friendly rather than aggressive teasing (Keltner, Young, Heerey, Oemig, \& Monarch, 1998) were found to be more likely to break up within a few months. Note though that the characteristics and functions of early dating relationships may be, at least partially, different from those of long-term established marriages. In the former, as noted by Martin (2007), good humor may even predict a quick break up if it is used to test alternatives and if good humor means high desirable status (see also Felmlee, 1995).

\section{Humor Styles, Adult Attachment, and Marital (In)stability}

Do humor styles contribute to marital (in)stability in a unique, specific way or are they simple artifacts of individual differences within the broader quality of romantic relationships such as adult attachment? This is an important question since the hypothesized role of humor styles on divorced versus married status could simply reflect positive versus negative quality in affects and cognitions relative to the image of the self and/or the image of the other in the relationship, and thus not add any specific value to the prediction.

There is indeed theoretic al and empirical evidence suggesting (a) that humor styles reflect individual differences in attachment (dimensions of anxiety and avoidance) and (b) that attachment insecurity may predict marital insatisfaction and instability. First, in a series of studies from different countries (Belgium, Canada, Lebanon, and the USA), self-defeating humor was found to be typical of people with insecure, especially anxious, adult attachment; the opposite seems to be the case with selfenhancing humor. Additionally, affiliative versus aggressive humor is more present among people with secure versus insecure, especially avoidant, adult attachment (Cann, Norman, Welbourne, \& Calhoun, 2008; Martin, 2007; Kazarian \& Martin, 2004; Saroglou \& Scariot, 2002; Taher, Kazarian, \& Martin, 2008). Second, attachment theory supports the idea that adult attachment insecurity should contribute to the vulnerability of marriage and its dissolution (Feeney \& Monin, 2008). Only very recently has this idea been tested. In one study, attachment security of wives and husbands with respect to their relationship, as assessed at their first child's transition to kindergarten after about eight years into marriage, revealed a long-term effect of attachment security on marital satisfaction, although it was not significantly related to the survival of the marriage over a 10-year period (Hirschberger, Srivastava, Marsh, Cowan, \& Cowan, 2009). In another study, among adults who had experienced their parents' divorce as children, those who were classified as secure in their attachment 
representations were less likely than insecure participants to divorce in the early years of marriage (Crowell, Treboux, \& Brockmeyer, 2009).

However, we hypothesized that, although humor styles and attachment with respect to the relationship may share some common variance in predicting divorced status, humor styles should provide a unique contribution to marital instability. Indeed, humor styles point to very specific acts that constitute "micro-events" in the everyday life and do not simply mirror the quality of the partners' relationship or one's own working models of self and the other in general. By its very nature, humor introduces something unique to human interactions that may contribute to, or even change, more stable emotional states, cognitive schemata, and working models. Positive humor styles may stabilize marriage (e.g., by reducing tension or by communicating warm feelings) in the presence of disagreement, conflict, or relational insecurity, while negative humor styles may destabilize marriage (e.g., by introducing tension or by communicating criticism) even in the presence of secure attachment, agreement, and harmony.

\section{Method}

Participants

Two samples of participants were included, one of married couples and the other of divorced couples. The first sample was composed of 98 married heterosexual couples (total $N=196$ ) who were approached by acquaintances of the second author and agreed to participate. The study was advertised as aiming "to explore different dimensions of family life, i.e. different aspects of partners' relationships, including humor". In selecting couples, we paid attention to the fact that at least one of the partners should have $a j o b$ and the age of participants should not be higher than 65. Effective age of participants varied between 26 and $62 \mathrm{yrs}$-old $(M=$ 45.8; $S D=8.7$ ) and the mean duration of marriage was 19.5 years. The mean number of children was 2.2. All couples lived in urban areas of the French-speaking part of Belgium. They were asked to fill in the protocols anonymously and separately and to send them back within four to six weeks. People were thanked for their participation and provided the option to be informed of results if they so wished. The second sample was composed of 48 divorced heterosexual couples. Participants (total $N=$ 96) were recruited through acquaintances of the third author under the same conditions as the first sample. Their mean age was 44.8 and the mean duration of the ended marriage was 13.5 years. Most of the couples had divorced just a few months earlier than the time of participation, and the others had been divorced 
between one and three years. Data were collected in 2002 (married couples) and 2004 (div orced couples).

In both samples, participants received a protocol in which they had to evaluate adult attachment dimensions, marital satisfaction, and the use of different humor styles (self-reports). In addition, they were requested to provide spouse-ratings, i.e. to evaluate the partner's (current spouse for the married couples, and ex-partner for the divorced) on the use of these different humor styles.

\section{Measures}

Humor Styles. Based on previous research and measures, five humor styles were investigated: affiliative, self-enhancing, aggressive, and self-defeating humor, as well as earthy humor. At the time of the data collection, the Humor Styles Questionnaire (HSQ; Martin et al., 2003) was only just emerging. We thus selected items from three existing different scales in order to tap, to the best extent, the content and specifics of each humor style: the HSQ (Martin et al., 2003; French translation by Saroglou \& Scariot, 2002), the Humorous Behavior Q-Sort Deck (HBQD: Craik et al., 1996; French translation by Lacour, 2002), and the Coping Humor Scale (CHS: Martin \& Lefcourt, 1983; French translation in Saroglou, 1999). Affiliative humor was measured through three items from the socially warm conduct pole in the HBQD and three others from the affiliative style of the HSQ. Self-enhancing humor was measured through three items from the CHS and three items from the self-enhancing style of the HSQ. Aggressive humor was measured through two items from the negative pole, "meanspirited", of the benign conduct in the HBQD, and four items from the aggressive style in the HSQ. Earthy humor was measured through six items from the earthy ( $v$ s. repressed) conduct of the HBQD, and self-defeating humor through six items from the self-defeating style in the HSQ.

In both self- and spouse-ratings, possible answers ranged from 1 (does not characterize me at all) to 5 (characterizes me totally). In order to increase reliability, three items (one for three different humor styles) were deleted when computing the aggregate for each style score. Humor styles were then measured in total by 27 items. Reliabilities were satisfactory, for both self- and spouse-ratings, among married participants (affiliative: .79 and .82; self-enhancing: .71 and .75; aggressive: .60 and .73; earthy: .58 and .72; and self-defeating: .77 and .73) as well as among divorced couples (affiliative: .81 and .83; self-enhancing: .69 and .75; aggressive: .78 and .79; earthy: .82 and .80; and self-defeating: .86 and .70). 
Here are sample items: (a) "I usually don't laugh or joke around much with other people" (affiliative; reverse keyed); (b) "If I am feeling depressed, I can usually cheer myself up with humor (self-enhancing); (c) "If someone makes a mistake, I will often tease them about it" (aggressive); (d) "I have a reputation for indulging in coarse or vulgar humor" (earthy); and (e) "I will often get carried away in putting myself down if it makes my family or friends laugh" (self-defeating).

Attachment Dimensions. Brennan, Clark, and Shaver's (1998) Experiences in Close Relationships is a 7-point Likert-format scale that contains 36 items measuring two orthogonal dimensions of attachment to the adult partner in the relationship: anxiety and avoidance. The scale is based on analyses of previous attachment scales and taps the underlying structure of these measures corresponding to two orthogonal axes, i.e. (a) anxiety about self and (b) discomfort with contact with others. The scale has higher psychometric qualities in comparison with previous multi-item attachment scales (Fraley, Waller, \& Brennan, 2000) and the two-factor structure in our French translation was confirmed in a previous study (Saroglou, Kempeneers, \& Seynhaeve, 2003). For this study, we selected 18 items (nine items for each dimension) that were found in Saroglou et al.'s (2003) study to have the highest loadings in their factor. The two-factor structure was once again well replicated and reliabilities were satisfactory for both anxiety and avoidance in married $(a=.80, .85)$ and divorced $(.83, .84)$ participants. Here are two sample items: "I worry a lot about my relationships" (anxiety) and "I try to avoid getting too close to my partner" (av oidance).

Marital Satisfaction. The Spanier Dyadic Adjustment Scale (Spanier, 1976) was administered as a commonly used 32-item measure of marital satisfaction (French translation by Baillargeon, Dubois, \& Marineau, 1986). The scale provides an evaluation of four dimensions of dyadic adjustment in couples: satisfaction, cohesion, consensus, and affective expression. For the analyses, we used the total score on marital satisfaction that we computed by summing the items of all the subscales (as $=.89$, for married, and .85 , for divorced couples). (Note that in the sample of married couples, the reliability of affective expression was low; this subscale was thus not included when computing the global mean score). Here are two sample items: "How often do you and your partner quarrel?" and "indicate the approximate extent of agreement or disagreement between you and your partner on amount of time spent together". 


\section{Results}

\section{Gender Differences across Raters and Ratings}

Table 1 details means and standard deviations of humor styles, in both self- and spouse-ratings, distinctly for men and women and for married and divorced participants. In married couples, when comparing self-reports, men, compared to women, reported higher use of affiliative humor, but also of aggressive and earthy humor. These differences were confirmed when comparing the spouse-ratings, with, in addition, self-enhancing humor being perceived as being higher among men (see Table 1). Moreover, when comparing the husband-ratings of wife's humor with husbands' and wives' self-reports, the former were significantly lower in all cases: husbands perceived wives as lower than them with respect to all humor styles, and the scores of the evaluations were also lower in comparison to wife's self-reports (all ps > .01). When comparing wife-ratings of husband's humor with husbands' and wives' self-reports, it turned out that wives perceived their husband to be higher than themselves in affiliative humor, $F=24.48, p<.001$ (and even more, compared to the husband's self-ratings; $F=5.46, p<.01)$, as well as in earthy humor $(24.69, p<.001)$, but lower in aggressive and self-defeating humor styles in comparison to husbands' self-reports $(3.68,5.66, p<.05)$.

Table 1. Self- and spouse-ratings of humor, distinctly for married and divorced couples.

\begin{tabular}{lcccccc}
\hline & Men's Humor $(M, S D)$ & \multicolumn{2}{c}{ Women's Humor $(M, S D)$} & \multicolumn{2}{c}{ Men > Women (F) } \\
\hline Humor Styles & Self-Ratings & Spouse-Rat. & Self-Ratings & Spouse-Rat. & Self-Rat. & Spouse-R. \\
\hline \multicolumn{7}{c}{ Married Couples $(N=98)$} \\
Affiliative & $3.70(0.83)$ & $3.90(0.92)$ & $3.30(0.85)$ & $3.08(0.76)$ & $12.29^{* * *}$ & $51.23^{* * *}$ \\
Self-enhancing & $3.01(0.78)$ & $2.93(0.89)$ & $2.83(0.87)$ & $2.49(0.68)$ & 2.14 & $14.17^{* * *}$ \\
Aggressive & $2.56(0.74)$ & $2.40(0.84)$ & $2.26(0.72)$ & $2.01(0.78)$ & $8.36^{* *}$ & $15.16^{* * *}$ \\
Earthy & $2.57(0.76)$ & $2.55(0.80)$ & $2.11(0.66)$ & $1.89(0.74)$ & $28.27^{* * *}$ & $48.44^{* * *}$ \\
Self-defeating & $2.22(0.86)$ & $2.01(0.84)$ & $2.07(0.74)$ & $1.88(0.71)$ & 1.89 & 1.66 \\
& & Divorced Couples (N = 48) & & \\
Affiliative & $2.90(0.58)$ & $2.71(0.54)$ & $2.76(0.45)$ & $2.64(0.49)$ & 1.71 & 0.35 \\
Self-enhancing & $2.95(0.68)$ & $2.50(0.83)$ & $2.60(0.93)$ & $2.36(0.87)$ & $3.98^{*}$ & 0.54 \\
Aggressive & $2.83(0.75)$ & $2.87(0.97)$ & $2.07(0.78)$ & $2.09(0.70)$ & $18.37^{* * *}$ & $23.62^{* * *}$ \\
Earthy & $3.17(1.07)$ & $3.33(0.87)$ & $2.14(0.83)$ & $1.77(0.40)$ & $36.28^{* * *}$ & $138.6^{* * *}$ \\
Self-defeating & $2.61(1.00)$ & $2.32(0.92)$ & $2.40(0.22)$ & $2.09(1.71)$ & 1.16 & 2.51 \\
\hline
\end{tabular}

${ }^{* * *} p<.001 .{ }^{* *} p<.01 .{ }^{*} p<.05$. 
In divorced couples, similarly to the married couples, men scored higher than women in self-reported use of aggressive and earthy humor and this was confirmed when comparing the spouse-ratings. However, they did not differ from women in use of affiliative humor; and the difference in self-enhancing humor, found in self-reports, was not confirmed by spouse-ratings. We also focused on cross-comparisons of selfratings with ex-spouse-ratings. Like in married couples, divorced men evaluated the mselves higher in all humor styles compared to the evaluations they made of their ex-spouses (all ps > .05), but, except for self-enhancing and self-defeating humor (Fs $=10.12$ and $8.81, \mathrm{ps}>.01$ ), the self-ratings were over-estimated compared to the exspouse-ratings. Women did not seem to discriminate in their evaluations between themselves and their ex-husbands, with the exception of the two negative humor styles, i.e. aggressive and earthy, for which they attributed higher scores to their exhusbands, Fs $=21.39,61.61, \mathrm{ps}>.001$. Finally, women evaluated themselves higher in self-enhancing, earthy, and self-defeating humor in comparison to how they were seen by their ex-spouses $(4.84,8.84$, and 9.47, all ps $>.05)$.

As far as attachment dimensions and marital satisfaction are concerned, no significant gender differences on these dimensions were found, for either the married or divorced participants.

Spouse-V alidation of Self-Ratings and Spouse Similarity on Humor

As detailed in Table 2, in both groups, importantly, spouses validated self-ratings for all humor styles. Distinct gender analyses did not show a gender effect on these results. The effects were however stronger in married, compared to divorced, couples for affiliative humor $(z=3.05, p<.01)$ and in divorced, compared to married couples $(z=2.65, p<.01)$, for self-defeating humor.

Table 2 also details coefficients of correlations when examining spouse similarity on humor styles. Three indicators of this similarity were computed, i.e. correlations in humor styles (a) between men's and women's self-ratings, (b) between men's ratings of women and women's ratings of men, and (c) between each participant's (distinctly for men and women) evaluations of the self and the spouse. Among married couples, an important similarity was found between men and women on their high or low use of aggressive, earthy, and self-defeating humor. Among divorced participants, there was also ex-spouse similarity on earthy humor and selfdefeating humor, though often at a marginal signific ance level (but note the much lower $N$ of this group). However, there was evidence of divorced partner dissimilarity on aggressive humor (at the self-ratings level, and in men's "minds", i.e. when 
crossing their self-ratings with their perception of women's humor) and affiliative humor (in spouse-ratings).

Table 2. Spouse-v alidation of self-ratings and between-spouse similarity on humor styles.

\begin{tabular}{|c|c|c|c|c|c|}
\hline \multirow[b]{2}{*}{ Humor Styles } & $\begin{array}{l}\text { Spouse- } \\
\text { Validation }\end{array}$ & \multicolumn{4}{|c|}{ Spouse Similarity } \\
\hline & $\begin{array}{l}\text { Spouse-Rating } \\
\times \text { Self-Ratings }\end{array}$ & $\begin{array}{l}\text { Self- } \\
\text { Ratings }\end{array}$ & $\begin{array}{l}\text { Spouse- } \\
\text { Ratings }\end{array}$ & $\begin{array}{l}\text { Men's Ratings: } \\
\text { Self } \times \text { Spouse }\end{array}$ & $\begin{array}{l}\text { Women's Ratings: } \\
\text { Self } \times \text { Spouse }\end{array}$ \\
\hline \multicolumn{6}{|c|}{ Married Couples (98 Couples) } \\
\hline Affiliative & $.59 * * *$ & .07 & .11 & -.02 & .06 \\
\hline Self-enhancing & $.39 * * *$ & -.05 & -.05 & .02 & $.14 \dagger$ \\
\hline Aggressive & $.50^{* * *}$ & .05 & $.23^{*}$ & $.36^{* * *}$ & $.36^{* * *}$ \\
\hline Earthy & $.59 * * *$ & $.29 * *$ & $.25^{*}$ & $.51^{* * *}$ & $.30^{* *}$ \\
\hline Self-defeating & $.46^{* * *}$ & $.15 \dagger$ & $.24^{*}$ & $.34^{* * *}$ & $.53^{* * *}$ \\
\hline \multicolumn{6}{|c|}{ Divorced Couples (48 Couples) } \\
\hline Affiliative & $.21^{*}$ & -.10 & $-.46^{* * *}$ & -.15 & .02 \\
\hline Self-enhancing & $.45^{* * *}$ & -.10 & $-.18 \dagger$ & $-.23 \dagger$ & -.12 \\
\hline Aggressive & $.61^{* * *}$ & $-.30 *$ & .14 & $-.47^{* * *}$ & .08 \\
\hline Earthy & $.62^{* * *}$ & $.23 \dagger$ & .11 & $.20 \dagger$ & $.23 \dagger$ \\
\hline Self-defeating & $.79 * * *$ & $.22 \dagger$ & $.26+$ & $.42^{* *}$ & .14 \\
\hline
\end{tabular}

${ }^{* * *} p<.001 .{ }^{* *} p<.01 .{ }^{*} p<.05 . \dagger p<.10$.

Mean Differences between Married and Divorced Couples

Mean differences (t-tests) were computed, distinctly for men and women, between married and divorced participants on measures of relationship quality and all humor styles (see Tables 3 and 4).

Table 3. Descriptive statistics $(M, S D)$ of quality of relationship measures and differences between married and divorced couples (distinct by gender information).

\begin{tabular}{|c|c|c|c|c|c|c|}
\hline \multirow[b]{2}{*}{ Relationship } & \multicolumn{2}{|c|}{ Married Couples } & \multicolumn{2}{|c|}{ Divorced Couples } & \multicolumn{2}{|c|}{$\begin{array}{l}\text { Differences: married } \\
\text { vs. divorced(t-†ests) }\end{array}$} \\
\hline & Men & Women & Men & Women & Men & Women \\
\hline Anxiety & $3.52(1.25)$ & $4.71(1.29)$ & $4.06(1.27)$ & $4.46(1.51)$ & $-2.43^{*}$ & $-3.12^{* *}$ \\
\hline Avoidance & $2.46(1.03)$ & $2.26(1.16)$ & $3.59(1.16)$ & $3.33(1.47)$ & $-5.98^{* * *}$ & $-4.76^{* * *}$ \\
\hline $\begin{array}{l}\text { Marital } \\
\text { satisfaction }\end{array}$ & $4.81(0.45)$ & $4.83(0.46)$ & $3.82(0.67)$ & $3.58(0.64)$ & $9.14^{* * *}$ & $11.99 * * *$ \\
\hline
\end{tabular}


Table 4. Differences between married and divorced couples on humor (t-tests).

\begin{tabular}{|c|c|c|c|c|}
\hline \multirow[b]{2}{*}{ Humor Styles } & \multicolumn{2}{|c|}{ Self-Ratings } & \multicolumn{2}{|l|}{ Spouse-Ratings } \\
\hline & Men & Women & Men's of Women & Women's of Men \\
\hline Affiliative & $6.74^{* * *}$ & $5.02^{* * *}$ & $4.23^{* * *}$ & $9.76^{* * *}$ \\
\hline Self-enhancing & 0.50 & 1.47 & 0.92 & $2.80^{* *}$ \\
\hline Aggressive & $-2.11^{*}$ & 1.48 & -0.59 & $-3.00 * *$ \\
\hline Earthy & $-3.96 * *$ & -0.23 & 1.26 & $-5.39 * * *$ \\
\hline Self-defeating & $-2.43^{*}$ & $-1.72 \dagger$ & $-1.64 \dagger$ & $-2.02 *$ \\
\hline
\end{tabular}

${ }^{* * *} p<.001 .{ }^{* *} p<.01 .{ }^{*} p<.05 . \dagger p<.10$.

As expected, both men and women who were divorced reported higher anxiety and avoidance in attachment, and lower marital satisfaction, compared to, respectively, married men and women. Moreover, regarding humor styles, consistently across genders and self- and spouse-ratings, married participants were characterized by a higher use of affiliative humor compared to divorced participants, whereas the latter were characterized by a higher use of self-defeating humor compared to married participants. In addition, men's use of aggressive and earthy humor, both as reported by themselves and by their partners, was more present among divorced than married couples. Finally, married, compared to divorced, women reported that their husband uses self-enhancing humor to a greater extent.

Humor Styles, Attachment, and Marital Satisfaction

Humor styles (self-reports) were associated with quality of attachment. As detailed in Table 5, married and divorced men's self-defeating humor was positiv ely related to their anxiety and/or avoidance; this was also the case with divorced women's selfdefeating humor and anxiety. Low self-enhancing humor was typical of anxiety among divorced men and women, as well as married women. High use of aggressive humor was related to married men's anxiety and divorced men's avoidance, but, on the contrary, it was low earthy humor that reflected insecure attachment among divorced women (both anxiety and avoidance) or among married men (avoidance). There was one surprising result, i.e. a positive association of divorced men's self-enhancing humor with avoidance, which may suggest the usefulness for men of humor as a coping mechanism which allows them to create distance from their partner through divorce. 
In order to clarify the humor-attachment links, given some interrelation between the two attachment dimensions, we computed, distinctly for men and women, multiple regression analyses on each humor style, using the two attachment dimensions as predictors. We treated the two samples, married and divorced participants as one (see Table 6). Self-enhancing and self-defeating humor reflected predominantly respectively, secure versus problematic - relation to the self, i.e. anxiety (but in men, self-defeating humor also reflected avoidance). On the contrary, affiliative and aggressive humor reflected predominantly, respectively, secure versus problematic concern for the other partner, i.e. avoidance. Finally, use of earthy humor seems "natural" to men whereas in women it even expresses security in attachment (both dimensions).

Table 5. Coefficients of correlations of humor styles with quality of relationship.

\begin{tabular}{|c|c|c|c|c|c|c|}
\hline \multirow[b]{3}{*}{ Humor Styles } & \multicolumn{2}{|c|}{ Anxiety } & \multicolumn{2}{|c|}{ Avoidance } & \multicolumn{2}{|c|}{ Marital satisfaction } \\
\hline & Men & Women & Men & Women & \multirow{2}{*}{$\begin{array}{l}\text { Men } \\
\text { Men/Womena }\end{array}$} & \multirow{2}{*}{$\begin{array}{l}\text { Women } \\
\text { Men/Womeno }\end{array}$} \\
\hline & & & & & & \\
\hline \multicolumn{7}{|c|}{ Married Couples $(N=98)$} \\
\hline Affiliative & .15 & -.12 & .01 & $-.24^{* *}$ & $-.13 / .08$ & $-.10 / .12$ \\
\hline Self-enhancing & -.00 & $-.29 * *$ & -.11 & -.14 & $.21 * / .08$ & $.22 * / .12$ \\
\hline Aggressive & $.17^{*}$ & .02 & .05 & .13 & $-.13 / .09$ & $-.09 / .00$ \\
\hline Earthy & -.06 & -.09 & $-.20^{*}$ & -.09 & $.02 / .17$ & $-.03 / .16$ \\
\hline Self-defeating & $.37^{* * *}$ & .12 & $.29 * *$ & -.10 & $-.12 /$ & $.02 / .13$ \\
\hline \multicolumn{7}{|c|}{ Divorced Couples ( $N=48)$} \\
\hline Affiliative & -.18 & .10 & .16 & -.04 & $.39 * * /-.20$ & $.50 * * /-.19$ \\
\hline Self-enhancing & $-.47^{* * *}$ & $-.32 *$ & $.48^{* * *}$ & .23 & $.04 / .32 *$ & $.10 / .10$ \\
\hline Aggressive & -.23 & -.16 & $.25^{*}$ & .18 & $-.32 * /-.35^{*}$ & $-.31 * /-.31 *$ \\
\hline Earthy & -.01 & $-.30^{*}$ & -.02 & $-.27^{*}$ & $-.39 * * /-.15$ & $-.29 * /-.10$ \\
\hline Self-defeating & -.04 & $.28^{*}$ & $.32 *$ & -.21 & $-.12 /-.10$ & $-.05 / .21$ \\
\hline
\end{tabular}

a Men's and women's humor.

${ }^{* * *} p<.001 .{ }^{* *} p<.01 .{ }^{*} p<.05$.

Correlations of men's and women's humor styles (self-ratings) with marital satisfaction provided specific results depending on marital status, as well as on whose satisfaction was considered and whose humor was involved (see Table 5). Humor styles did not seem to play a major role on marital satisfaction among married couples, with two notable exceptions: Men's self-enhancing humor was associated with increased marital satisfaction of both men and women. And women's selfdefeating humor was associated with increased men's marital satisfaction. On the contrary, marital satisfaction among div orced couples was clearly a function of the 
pro- vs. anti-social character of three humor styles. Aggressive humor in both men and women was an indicator of low marital satisfaction of both ex-spouses. And men's use of affiliative and earthy humor was related to, respectively, high and low marital satisfaction of both partners (significantly of men).

Table 6. Regression of attachment dimensions on humor styles ( $\beta s)$.

\begin{tabular}{llllllll}
\hline & \multicolumn{2}{l}{ Men $(N=146)$} & & \multicolumn{3}{l}{ Women $(N=146)$} \\
\cline { 2 - 3 } Humor Styles & Anxiety & Avoidance & $R^{2}$ & & Anxiety & Avoidance & $R^{2}$ \\
\hline Affiliative & -.01 & $-.16 \dagger$ & .03 & & $-.14 \dagger$ & $-.28^{* * *}$ & .10 \\
Self-enhancing & $-.16 \dagger$ & .07 & .03 & & $-.32^{* * *}$ & -.03 & .10 \\
Aggressive & .04 & $.17^{*}$ & .03 & & -.08 & .09 & .01 \\
Earthy & .02 & .03 & .01 & & $-.16^{*}$ & $-.15 \dagger$ & .05 \\
Self-defeating & $.20^{*}$ & $.32^{* * *}$ & .16 & & $.23^{* *}$ & -.09 & .06 \\
\hline
\end{tabular}

${ }^{* * *} p<.001 .{ }^{* *} p<.01 .{ }^{*} p<.05 . \dagger p<.10$.

Unique Effects of Humor Styles and Attachment on Divorced Status

Humor styles reflected quality in attachment; and both humor and attachment were found to differ when comparing married to divorced couples. We investigated whether humor styles may uniquely predict marital status, independently of the effect of attachment.

Before computing multiple regressions, and In order to avoid risks of multicolinearity and to maximize conciseness in the presentation of results, we integrated the five humor styles into three higher order types using an exploratory factor analysis (PCA) with varimax rotation (eigenvalue $>1$ ). In men, aggressive and earthy humor constituted the first factor (loadings: .87 and .84); affiliative and self-enhancing humor constituted the second (.86 and .80); and self-defeating humor (.95) was the last factor. With one exception (.33), no second loading was higher than .13; and total variance explained was $79 \%$. Extraction of three factors among women replicated this pattern with affiliative and self-enhancing humor constituting the first factor (.89 and .80), aggressive and earthy the second (.80 and .74), and selfdefeating the third (.92; total variance explained $=75 \%$ ). We then averaged, for each factor, the respective humor styles and computed the subsequent analyses with three humor types, i.e. (a) constructive humor (affiliative and self-enhancing), (b) antisocial humor (aggressive and earthy), and (c) self-defeating humor. Note that in a previous study where different humor measures were factor-analyzed, 
aggressive and earthy (otherwise "boorish") humor styles were found to compose one broad factor, labeled "bawdy humor", that mainly reflected negative individualism (Kirsh \& Kuiper, 2003).

Table 7. Logistic regression of humor styles and attachment on divorced (versus marred) status.

\begin{tabular}{|c|c|c|c|c|c|c|}
\hline \multirow[b]{2}{*}{ Predictors } & \multicolumn{3}{|c|}{ Men } & \multicolumn{3}{|c|}{ Women } \\
\hline & $A$ & Wald & $p$ & $A$ & Wald & $P$ \\
\hline \multicolumn{7}{|l|}{ First step } \\
\hline Constructive humor & -1.24 & 13.17 & .000 & -1.03 & 10.74 & .001 \\
\hline Antisocial humor & 0.92 & 9.87 & .002 & -0.14 & 0.16 & .688 \\
\hline Self-defeating humor & 0.56 & 6.29 & .012 & 0.56 & 7.01 & .008 \\
\hline \multicolumn{7}{|c|}{$R^{2}=.20$ (Men), .11 (Women) } \\
\hline \multicolumn{7}{|c|}{ Second step } \\
\hline Constructive humor & -1.20 & 10.65 & .001 & -0.91 & 6.39 & .011 \\
\hline Antisocial humor & 0.87 & 7.73 & .005 & -0.08 & 0.05 & .824 \\
\hline Self-defeating humor & 0.06 & 0.06 & .804 & 0.61 & 6.53 & .011 \\
\hline Anxiety & 0.26 & 2.04 & .153 & 0.27 & 3.07 & .080 \\
\hline Avoidance & 0.96 & 17.77 & .000 & 0.69 & 17.63 & .000 \\
\hline$R^{2}=.32$ (Men), .25 (Wom & & & & & & \\
\hline
\end{tabular}

In order to examine whether the humor styles play a unique role on marital status or whether this role is mainly an artifact of the quality of attachment, we performed a logistic regression analysis with marital status as a dichotomous dependant variable. In the first step, the three humor styles (self-reports) were entered as predictors, and in the second step the two attachment dimensions were added. This analysis was carried out separately for men and women.

As detailed in Table 7, in both men and women, low constructive humor and high self-defeating humor was predictive of divorce. Additional predictor of divorce was men's use of antisocial humor. When the two attachment dimensions, i.e. avoidance and anxiety, were entered into the regression, they were found to be, respectively, a clear and a marginal predictor of divorce. Furthermore, with the addition of these factors, the role of men's self-defeating humor in predicting divorce disappeared, but all the other effects of humor types (self-defeating among women, antisocial among men, and constructive among both men and women) remained signific ant. 


\section{Discussion}

Using data from two samples composed of married and divorced couples, we investigated, cross-sectionally, how humor styles of both men and women (a) are related to two aspects of the quality of a marital relationship, i.e. quality of attachment to the partner and marital satisfaction, and (b) differed when comparing divorced with married couples. We also investigated the unique role of humor styles in predicting divorce, beyond the role of attachment dimensions. The results overall confirm the expected links and provide, in some cases, more nuanced information when one distinguishes between (a) div orced and married couples, (b) men and women, and (c) different styles from the broad categories of the so-called "positive" and "negative" humor.

\section{Humor Styles and Attachment}

In line with previous studies on humor styles and attachment reviewed in the Introduction, it turned out that humor styles which are directed tow ards others, either by including them (affiliative) or by disparaging them (aggressive), reflect, respectively, a positive and negative model of the other person in attachment (avoidance dimension). The humor styles that aim to strengthen the self in the face of adversity (self-enhancing) or to disparage the self in order to gain others' acceptance (self-defeating) reflect, respectively, a positive or negative image of the self in attachment (anxiety dimension). The additional fifth style, earthy (nonrepressed) humor, seems to be "natural" for men, i.e., independent from attachment quality, and to even reflect secure attachment in women. Alternatively, it may be that insecure women tend to feel uncomfortable with, and "inhibit", the expression of earthy humor, a humor style that is very likely socially perceived as inappropriate for them.

\section{Humor Styles in Married Couples}

The secure versus insecure, in terms of attachment, quality of each humor style did not necessarily imply a face-to-face correspondence with positive versus negative consequences for the quality and stability of partners' relationship. In addition, the role of men's and women's humor styles on relationship satisfaction seemed to be modest within the context of married couples. Married men's use of self-enhancing humor indicated high marital satisfaction of both themselves and their wives. This was very likely due to the nature of this humor style which is used to cope with life's 
everyday stresses and to find amusement in life's incongruities. In stable long-term relationships, self-enhancement humor can thus be an efficient tool for increasing relationship satisfaction. Moreover, women's self-defeating humor seemed to contribute to men's, but not women's, marital satisfaction. This unexpected result (see also below for the detrimental role of this humor style on marital stability), if not due to chance, could be interpreted as an indication of a traditional gender asymmetry in marriage. Women's self-ridiculization through humor may please husbands and increase their marital satisfaction. This can be facilitated by the fact that self-defeating humor does not explicitly attest asymmetry: "it was only a joke".

The fact that it was men's and not women's self-enhancing humor that seemed to play a role on both partners' satisfaction may also be understood in terms of gender differences. Men and women, especially in married couples, seemed to agree, consistently across judgments of self and the spouse, that men use humor - all styles except self-defeating - more than women. Married husbands may then contribute to both spouses' marital satisfaction by using the prototypical - in terms of positive coping - humor style. Another explanation can be provided by the results on married spouse similarity on humor styles. Consistently across (a) self-perceptions, (b) spouse-ratings, and (c) evaluations of self versus spouse, there was a similarity between the two spouses on the high or low use of the three very "specific" in content, negative in emotionality, and low in frequency humor styles: earthy, aggressive, and self-defeating. On the contrary, no spouse similarity was observed on the use of the two more common, positive humor styles, i.e. affiliative and selfenhancing. Thus, it may be the use of one of these two humor styles (self-enhancing) by at least one partner (husband) that makes the difference in the marital satisfaction of both spouses.

One could be surprised by the fact that no other humor style - especially the aggressive style - showed an association with marital satisfaction. This was also true of the perception each partner had of the spouse's humor. It may be that, in the present sample of couples with 20 years of average marriage duration, the variability of marital satisfaction and the humor-marital satisfaction association are lower in comparison to recent studies that have investigated this question among students in general (Cann et al., 2008), students in dating couples (Butzer \& Kuiper, 2008; Campbell et al., 2008), newlywed couples (Driver \& Gottman, 2004), or married couples with much shorter marriage duration (De Koning \& Weiss, 2002).

Note that the between-spouse similarity in the use of the three negative humor styles (earthy, aggressive, and self-defeating) but not the two positive styles (affiliative and 
self-enhancing) can be understood in the light of previous research on spouse similarity in personality traits and values. Recent research suggests that there exists moderate spouse congruence on agreeableness, conscientiousness, and openness to experience, but not on extraversion and neuroticism, where congruence is close to zero (Rammste dt \& Schupp, 2008; see also Lee, Ashton, Pozzebon, Visser, Bourdage, \& Ogunfowora, 2009, for similar findings in friendships). The first two personality dimensions constitute the two "moral traits" in personality (Cawley, Martin, \& Johnson, 2000); and openness to experience reflects (low) conservatism in values and related sociocognitive dimensions and social behaviors (McCrae \& Sutin, 2009). Interestingly, the major personality correlate of the two positive humor styles, as of humor in general, is extraversion, whereas aggressive and self-defeating humor are characterized, in addition to neuroticism, by low agreeableness and conscientiousness (Galloway, 2010; Martin, 2007; Saroglou \& Scariot, 2002; Vernon, Martin, Schermer, \& Mackie, 2008) and high psychopathy and machiavellianism (Veselka et al., 2010); and earthy humor correlates mainly with openness to experience (Craik \& Ware, 1998). In other words, spouses may differ on the use of general/social humor, but they are similar on the high or low use of humor styles that reflect respect or transgression of interpersonal and social values and norms such as aggressive and earthy humor.

Humor Styles in Divorced Couples

Much more extended, but still gender-specific, was the role of humor styles in predicting divorce and (retrospectively reported) relationship quality among divorced couples. In line with the findings on married couples, men's low use of selfenhancing humor - at least on the basis of spouse-ratings - predicted divorced, compared to marital, status. In addition, both male and female ex-spouses, and consistently across self- and spouse-ratings, reported lower use of affiliative humor and higher use of self-defeating humor, in comparison to married couples. Moreover, men's high aggressive and earthy humor, measured through both selfand spouse-ratings, predicted divorced versus marital status. With the exception of self-defeating humor, which turned out to mirror insecure attachment, all other humor styles remained significant predictors of divorce, once attachment dimensions were also entered in the regression (which also controlled for betweenhumor styles overlap). As expected, insecure attachment, with regard to the partner, was higher in divorced than married couples; and divorced men and women tended to be both anxious and avoidant. But beyond these effects, low use of constructive humor by both men and women, high use of antisocial humor (earthy 
and aggressive) by men, and high use of self-defeating humor by women, uniquely and additiv ely predicted divorce.

When focusing on "assumed" spouse differences, i.e. those established when evaluating one's own humor versus spouse's humor, it turned out that divorced men were similar to married men in discriminating between themselves and their (ex)wives by attributing to them less humor of any style. However, divorced women did not attribute a greater use of affiliative humor to their ex-spouse compared to themselves, contrary to what married women did. They may have "underestimated" their ex-partner's use of positive humor, or they may have somehow integrated the fact that ex-husbands are not so good at using it (what seemed to be the case when comparing married to divorced men in self-reports). Or, finally, divorced men may have "overestimated" their use of positive humor. Obviously, in divorced couples, there is a discrepancy in perceptions of men's use of positive humor. Interestingly, there was no such discrepancy with regard to aggressive and earthy humor for which the gender differences were consistent, across judgments and judges, in favor of a higher use of these humor styles by men.

Additional information was obtained when examining spouse-validation of selfreports as well as spouse similarity on humor styles. Like in married couples, there was, in divorced couples, (a) spouse-validation of self-ratings in all humor styles, and (b) spouse similarity, consistently across judges and judgments, on earthy and selfdefeating humor. This could be understood by the fact that the ex-partners were, at one time in the past, probably dating, and certainly married. Obviously, like the still married couples, they had an accurate perception of the partner's humor; and they shared similarities on humor styles that reflect (a) conventionalism or transgression of social norms and openness to experience (earthy humor) and (b) neurotic tendency for self-diminishment in order to please others (self-defeating). However, unlike the married couples, affiliative humor in divorced people received weak spousevalidation, and, more importantly, together with aggressive humor, it constituted a domain of dissimilarity between partners. In other words, partner dissimilarity in the pro- versus anti-social quality of humor used seems to be an additional characteristic of div orced compared to married couples.

Note, finally, that the hypothesized role of prosocial and antisocial humor in predicting high versus low relationship satisfaction was found to be significant among divorced couples, which was not the case in married couples. Presumably, among the former, hostility and low warmth in the relationship, including when joking, but also dissimilarity between men and women on this form of humor, 
decreased relationship satisfaction, increased the explosiveness of the couple in the presence of vulnerabilities and adversities, and led to relationship dissolution. On the contrary, prosocial and non-hostile humor, as well as spouse similarity on these constructs, may not be a necessary indicator of marital satisfaction among partners who have already enjoyed marital stability for many years; if not, they should have had div orced.

In sum, marital instability and insatisfaction among divorced people seem to occur (a) not only in the context of men's and women's insecure attachment, but also when partners (b) make insufficient use of positive, constructive humor, (c) make high use of antisocial (aggressive and earthy) humor (especially men), (d) differ in interpersonal warmth or hostility when using humor, (e) misperceive men-women differences in the use of positive humor, and (f) make high use of self-disparaging humor (especially women).

Limitations and Questions for Future Research

Despite the interest of presenting and comparing data on specific humor styles from divorced versus married couples, this study presents important limitations. The crosssectional design prohibits any attribution of causality and causal direction. Although there is important longitudinal research in favor of the idea that humor itself and humor interaction predict changes in a relationship months and years later, it cannot be totally excluded that divorced participants accentuated negativity in humor evaluations, in line with their stereotypical perceptions of reasons leading to div orce. On the other hand, whereas div orced participants filled in the questionnaires without reciprocal consultation, we had no control on married partners who could have communicated with each other when providing their responses.

These limitations constitute challenges to be faced in future research through more careful, ideally longitudinal, designs, and behavioral and observational measures not only of humor styles of each partner but also of their humor interaction. Studying specific humorous responses during interactions can provide more nuanced information on the impact humor has on interpersonal relationships. Idiographic assessment of humor seems to better predict intra-individual variability as a function of the situation and context than do nomothetic approaches of humor that assess only between-person differences (Caldwell, Cervone, \& Rubin, 2008). As briefly evoked in the Introduction, the role of a specific humorous response (e.g., of affiliative type), even within the same individuals and with respect to the same domain, i.e. romantic relationships, may have different functions and effects 
depending on whether this occurs before dating (attractiveness), during dating (comparative testing of alternatives), marriage (stability), divorce (successful dissolution), or the post-divorce period (ex-spouses' continuation of co-parenting).

Another issue that arises from the present findings is that both partners' humor styles seem to have an impact on marital insatisfaction and dissolution, but, in several cases, this was in a way that paralleled gender differences on personality. Men are typically found to be less agreeable and more aggressive, whereas women more neurotic (Lippa, in press). It may then be that, to some point, the problem for marital satisfaction and stability comes from men's excessive use of "masculine" humor (aggressive and earthy) and women's excessive use of "feminine" humor (selfdefeating). It could thus be interesting to investigate in future research whether the role of humor styles in predicting divorce simply reflects basic personality tendencies that are gender-specific or plays a unique and additive effect.

Moreover, the impact of humor styles on relationship satisfaction and stability may be stronger or clearer once other individual differences are included in the study as moderators. For instance, Kuiper and Borowicz-Sibenik (2005) found that the relation between humor and indicators of well-being was clearer for people who "needed" it because of their low agency and low communion. The latter are important also for functioning in close relationships, and humor may thus be particularly beneficial to partners who are low on these dimensions.

Finally, it is needless to say that the present work was purely descriptive of psychological processes, and not evaluative of the personal and social quality of the human realities studied: marriage, divorce, and humor. Independently of whether particular humor styles may have a facilitative or deleterious effect on marital stability or dissolution, it is our pleasure to offer the reminder that, when one faces, for instance, the conflict between maintaining his/her aggressive humor style and allowing the relationship to collapse, the decision is a question of personal taste or ethical judgment. Psychological research only informs, and we, humans, are free to make choices, or at least to believe that we are.

Note

The results of the present study were presented at the $18^{\text {th }}$ International Society for Humor Studies Conference, Copenhagen, Denmark (July 2006). 


\section{References}

Baillargeon, J., Dubois, G., \& Martineau, R. (1986). Traduction française de l'Echelle d'Ajustement Dyadique [A French translation of the Dyadic Adjustment Scale]. Revue Canadienne des Sciences du Comportement, 18, 25-34.

Brennan, K. A., Clark, C. L., \& Shaver, P. R. (1998). Self-report measurement of adult attachment: An integrative overview. In J. A. Simpson \& W. S. Rholes (Eds.), Attachment theory and close relationships (pp. 46-76). New York: Guilford Press.

Bressler, E. R., \& Balshine, S. (2006). The influence of humor on desirability. Evolution and Human Behavior, 27, 29-39.

Butzer, B., \& Kuiper, N. A. (2008). Humor use in romantic relationships: The effects of relationship satisfaction and pleasant versus conflict situation. The Journal of Psychology, 142, 245-260.

Campbell, L., Martin, R. A., \& Ward, J. R. (2008). An observational study of humor use while resolving conflict in dating couples. Personal Relationships, 15, 41-55.

Caldwell, T. L., Cervone, D., \& Rubin, L. H. (2008). Explaining intra-individual variability in social behavior through idiographic assessment: The case of humor. Journal of Research in Personality, 42, 1229-1242.

Cawley, M. J., III, Martin, J. E., \& Johnson, J. A. (2000). A virtue approach to personality. Personality and Individual Differences, 28, 997-1013.

Cann, A., Norman, M. A., Welbourne, J. L., \& Calhoun, L. G. (2008). Attachment styles, conflict styles, and humour styles: Inter-relationships and associations with relationship satisfaction. European Journal of Personality, 22, 131-146.

Cohan, C. L., \& Bradbury, T. N. (1997). Negative life events, marital interaction, and the longitudinal course of newlywed marriage. Journal of Personality and Social Psychology, 73, 114-128.

Craik, K. H., Lampert, M. D., \& Nelson, A. J. (1996). Sense of humor and styles of everyday humorous conduct. In W. Ruch (Ed.), Measurement approaches to the sense of humor [special issue]. Humor: International Journal of Humor Research, 9, 273-302.

Craik, K. H., \& Ware, A. P. (1998). Humor and personality in everyday life. In W. Ruch (Ed.), The sense of humor: Explorations of a personality characteristic (pp. 63-94). Berlin, Germany: Mouton de Gruyter. 
Crowell, J. A., Treboux, D., \& Brockmeyer, S. (2009). Parental divorce and adult children's attachment representations and marital status. Attachment and Human Development, 11, 87-101.

De Koning, E., \& Weiss, R. L. (2002). The relational humor inventory: Functions of humor in close relationships. American Journal of Family Therapy, 20, 1-18.

Demeure, M.-E. (2004). Humor styles, adult attachment, and marital insatisfaction in divorced couples (Unpublished master's thesis). Université catholique de Louvain, Louvain-la-Neuve, Belgium.

Driver, J. L., \& Gottman, J. M. (2004). Daily marital interactions and positive affect during marital conflict among newlywed couples. Family Process, 43, 301-314.

Doris, P. (2004). The Humor Styles Questionnaire: Investigating the role of humor in psychological well-being (Unpublished doctoral dissertation). University of Western Ontario, London, Canada.

Feeney, B. C., \& Monin, J. K. (2008). An attachment-theoretical perspective on divorce. In J. Cassidy \& P. R. Shaver (Eds.), Handbook of attachment: Theory, research, and clinical applications (pp. 934-957). New York: Guilford Press.

Felmlee, D. H. (1995). Fatal attractions: Affection and disaffection in intimate relationships. Journal of Personal and Social Relationships, 12, 295-311.

Fitts, S. D., Sebby, R. A., \& Zlokovich, M. S. (2009). Humor styles as mediators of the shyness-loneliness relationship. North American Journal of Psychology, 11, 257-272.

Fraley, B., \& Aron, A. (2004). The effect of a shared humorous experience on closeness in initial encounters. Personal Relationships, 11, 61-78.

Fraley, R. C., Waller, N. G., \& Brennan, K. A. (2000). An item response theory analysis of self-report measures of adult attachment. Journal of Personality and Social Psychology, 78, 350-365.

Frewen, P. A., Brinker, J., Martin, R. A., \& Dozois, D. J. A. (2008). Humor styles and personality-vulnerability to depression. Humor: International Journal of Humor Research, $21,179-195$.

Galloway, G. (2010). Individual differences in personal humor styles: Identification of prominent patterns and their associates. Personality and Individual Differences, 48, 563567. 
Gottman, J. M. (1994). What predicts divorce? The relationship between marital processes and marital outcomes. Hillsdale, NJ: Lawrence Erlbaum.

Gottman, J. M., Coan, J., Carrere, S., \& Swanson, C. (1998). Predicting marital happiness and stability from newlywed interactions. Journal of Marriage and the Family, 60, 5-22.

Gottman, J. M., \& Levenson, R. W. (1999). Rebound from marital conflict and divorce prediction. Family Process, 38, 287-292.

Herzog, T. R., \& Anderson, M. R. (2000). Joke cruelty, emotional responsiveness, and joke appreciation. Humor: International Journal of Humor Research, 13, 333-351.

Herzog, T. R., \& Karafa, J. A. (1998). Preferences for sick versus non-sick humor. Humor: International Journal of Humor Research, 11, 291-312.

Hirschberger, G., Srivastava, S., Marsh, P., Cowan, C. P., \& Cowan, P. A. (2009). Attachment, marital satisfaction, and divorce during the first fifteen years of parenthood. Personal Relationships, 16, 401-420.

Johnson, M. D. (2002). The observation of specific affect in marital interactions: Psychometric properties of a coding system and a rating system. Psychological Assessment, 14, 423-438.

Kazarian, S. S., \& Martin, R. A. (2004). Humor styles, personality, and well-being among Lebanese university students. European Journal of Personality, 18, 209-219.

Keltner D., Young, R. C., Heerey, E. A., Oemig, C., \& Monarch, N. D. (1998). Teasing in hierarchical and intimate relations. Journal of Personality and Social Psychology, 75, 1231-1247.

Kirsh, G. A., \& Kuiper, N. A. (2003). Positive and negative aspects of sense of humor: Associations with the constructs of individualism and relatedness. Humor: International Journal of Humor Research, 16, 33-62.

Kuiper, N. A., \& Borowicz-Sibenik, M. (2005). A good sense of humor doesn't always help: Agency and communion as moderators of psychological well-being. Personality and Individual Differences, 38, 365-377.

Kuiper, N. A., \& McHale, N. (2009). Humor styles as mediators between self-evaluative standards and psychological well-being. The Journal of Psychology, 143, 359-376. 
Lacour, C. (2002). Humor styles, adult attachment, and marital satisfaction (Unpublished master's thesis). Université catholique de Louvain, Louvain-la-Neuve, Belgium.

Laver, R. H., Laver, J. C., \& Kerr, S. T. (1990). The long-term marriage: Perceptions of stability and satisfaction. International Journal of Aging and Human Development, 31, 189-195.

Lee, K., Ashton, M. C., Pozzebon, J. A., Visser, B. A., Bourdage, J. S., \& Ogunfowora, B. (2009). Similarity and assumed similarity in personality reports of well-acquainted persons. Journal of Personality and Social Psychology, 96, 460-472.

Lippa, R. A. (2007). The preferred traits of mates in a cross-national study of heterosexual and homosexual men and women: An examination of biological and cultural influences. Archives of Sexual Behavior, 36, 193-208.

Lippa, R. A. (in press). Sex differences in personality traits and gender-related occupational preferences across 53 nations: Testing evolutionary and social environmental theories. Archives of Sexual Behavior.

Martin, R. A. (2007). The psychology of humor: An integrative approach. New York: Academic Press.

Martin, R. A., \& Lefcourt, H. M. (1983). Sense of humor as a moderator of the relation between stressors and moods. Journal of Personality and Social Psychology, 45, 13131324.

Martin, R. A., Puhlik-Doris, P., Larsen, G., Gray, J., \& Weir, K. (2003). Individual differences in uses of humor and their relation to psychological well-being: Development of the Humor Styles Questionnaire. Journal of Research in Personality, 37, 48-75.

Matthews, L. S., Wickrama, K. A. S., \& Conger, R. D. (1996). Predicting marital instability from spouse and observer reports of marital interaction. Journal of Marriage and the Family, 58, 641-655.

McCrae, R. R., \& Sutin, A. R. (209). Openness to experience. In M. R. Leary \& R. H. Hoyle (Eds.), Handbook of individual differences in social behavior (pp. 257-273). New York: Guilford Press.

Murstein, B. I., \& Brust, R. G. (1985). Humor and interpersonal attraction. Journal of Personality Assessment, 49, 637-640. 
Priest, R. F., \& Thein, M. T. (2003). Humor appreciation in marriage: Spousal similarity, assortative mating, and disaffection. Humor: International Journal of Humor Research, 16, 63-78.

Rammstedt, B., \& Schupp, J. (2008). Only the congruent survive: Personality similarities in couples. Personality and Individual Differences, 45, 533-535.

Rodrigues, A. E., Hall, J. H., \& Fincham, F. D. (2006). What predicts divorce and relationship dissolution? In M. A. Fine \& J. H. Harvey (Eds.), Handbook of divorce and relationship dissolution (pp. 85-112). Mahwah, NJ: Lawrence Erlbaum.

Rust, J., \& Goldstein, J. (1989). Humor in marital adjustment. Humor: International Journal of Humor Research, 2, 217-223.

Saroglou, V. (1999). Humor, religion, and personality (Unpublished doctoral dissertation). Université catholique de Louvain, Louvain-la-Neuve, Belgium.

Saroglou, V. \& Anciaux, L. (2004). Liking sick humor: Coping styles and religion as predictors. Humor: International Journal of Humor Research, 17, 257-277.

Saroglou, V., Kempeneers, A., \& Seynhaeve, I. (2003). Need for closure and adult attachment dimensions as predictors of religion and reading interests. In P. Roelofsma, J. Corveleyn, \& J. van Saane (Eds.), One hundred years of psychology and religion (pp. 139-154). Amsterdam: VU University Press.

Saroglou, V., \& Scariot, C. (2002). Humor Styles Questionnaire: Personality and educational correlates in Belgian high school and college students. European Journal of Personality, 16, 43-54.

Spanier, G. B. (1976). Measuring dyadic adjustment: New scales of assessing the quality of marriage and similar dyads. Journal of Marriage and the Family, 38, 15-28.

Taher, D., Kazarian, S. S., \& Martin, R. A. (2008). Validation of the Arabic Humor Styles Questionnaire in a community sample of Lebanese in Lebanon. Journal of Cross-Cultural Psychology, 39, 552-564.

Tümkaya, S. (2007). Burnout and humor relationship among university lecturers. Humor: International Journal of Humor Research, 20, 73-92. 
Vernon, P. A., Martin, R. A., Schermer, J. A., \& Mackie, A. (2008). A behavioral genetic inv estigation of humor styles and their correlations with the Big-5 personality dimensions. Personality and Individual Differences, 44, 1116-1125.

Vernon, P. A., Villani, V. C., Schermer, J. A., Kirilovic, S., Martin, R. A., Petrides, K.V., Spector, \& Cherkas, L. F. (2009). Genetic and environmental correlations between trait emotional intelligence and humor styles. Journal of Individual Differences, 30, 130-137.

Veselka, L., Schermer, J. A., Martin, R. A., \& Vernon, P. A. (2010). Relations between humor styles and the Dark Triad traits of personality. Personality and Individual Differences, 48, 772-774.

Ziv, A. (1988). Humor's role in married life. Humor: International Journal of Humor Research, 1, 223-229.

Ziv , A., \& Gadish, O. (1989). Humor and marital satisfaction. Journal of Social Psychology, 129, 759-768.

About the authors:

Vassilis Saroglou, Ph.D., is professor of psychology at the Université catholique de Louvain, Division of social psychology. He has extensive research on personality and social psychology of religion, as well as psychology of humor from a personality and positive emotions perspective.

Address for correspondence: Prof. Vassilis Saroglou UCLouvain, Dept. of psychology, Centre for psychology of religion, Division of social and organizational psychology, $\mathrm{Pl}$. du Cardinal Mercier 10 B-1348 Louvain-la-Neuve, Belgium

Email: vassilis.saroglou@uclouv ain.be

Christelle Lacour holds a master's degree in psychology from the Université catholique de Louvain. Data and results from the sample of married couples were first presented in her master's thesis (2002).

Marie-Eve Demeure holds a master's degree in psychology from the Université catholique de Louvain. Data and results from the sample of divorced couples were first presented in her master's thesis (2004). 